\title{
GREEN ECONOMY WORKSHOP : MEMPERSIAPKAN WIRAUSAHA MUDA YANG BERWAWASAN LINGKUNGAN DI SMKN 3 BANJARMASIN
}

Green Economic Workshop : Preparing Environmental Friendly Young Entrepreneurship In SMKN 3 Banjarmasin

\author{
Oleh. \\ Rizka Zulfikar, S.Tp, MM ${ }^{1]}$, Prihatini Ade Mayvita, SE, MM ${ }^{2]}$ \\ ${ }^{1]}{ }^{2]}$ Fakultas Ekonomi Universitas Islam Kalimantan MAB - Banjarmasin \\ ${ }^{11}$ rizkazulfikar@gmail.com,${ }^{2]}$ ademayvita@gmail.com
}

\section{Abstract}

At present, environmental issues is an important concern for the whole world along with the many problems that threated the environment such as global warming, ozone layer depletion, and also water and soil pollution. The implementation of the green economy as a form of public awareness of how importance environment is to the future has been intensively conducted. School can be a right media, a comfortable and dynamic system for students to develop good knowing, good filling and good acting based on the environment.

The small number of environmental knowledge in educational subject received by students at SMKN 3 Banjarmasin, made the students mindset of environmental and motivate to apply the concepts of green economy in their environment has not been established and it will be a priority issue agreed between proposer and partners.

Implementation of this community development activities had taken the form of workshops and carried out with lectures, discussions and audio visual media presentation. Lectures and discussions had conducted for the subjects (a) The definition of Green Economy and government policies relating to green economic concepts, (b) The purpose of green economy concepts, (c) Knowing the environmental damage due to non-application of green economy. (d) How to Applicated the green economic concepts in the student environment and society, (e) Simply application of the 3 pillars of the green economy (Reuse, Reduce and Recycle), (f) Introduction and empower the business opportunities in the era of green economy, (g) Introduction the practice of making edible water bottle as environmental friendly products and as an alternative replaced product for plastic cups used.

The Evaluation technic of this community development activities carried out to assess the succestiveness of this event had conducted in the form of giving pre and post test related the subject matter had discussed in this activity. This test is to determine the effect of this community development activities to give added value on knowledge and motivation of all participants to preparing the sudents as an environmental friendly young entrepreneurship.

Keywords : Green Economy, Entrepreneurship, Environmental Friendly.

\section{Abstrak}

Isu lingkungan hidup hingga saat ini menjadi perhatian penting bagi seluruh dunia seiring dengan banyaknya masalah yang mengancam lingkungan hidup manusia seperti global warming, 
penipisan lapisan ozon, pencemaran udara, air dan tanah. Penerapan green economy sebagai bentuk kesadaran masyarakat dunia akan pentingnya lingkungan terhadap masa depan telah gencar dilakukan. Sekolah dapat menjadi wahana dan sistem yang nyaman dan dinamis bagi siswa untuk mengembangkan good knowing, good filling, dan good acting tentang lingkungan hidup.

Masih sedikitnya pengetahuan dan pendidikan berwawasan lingkungan yang diterima oleh para siswa di SMKN 3 Banjarmasin, belum terbentuknya pola pikir berwawasan lingkungan dan belum termotivasinya para siswa untuk menerapkan konsep-konsep green economy di lingkungan mereka. menjadi persoalan prioritas yang disepakati pengusul dan mitra.

Pelaksanaan kegiatan pengabdian masyarakat ini dalam bentuk workshop dengan metode ceramah, diskusi dan presentase dengan media audio visual. Ceramah dan diskusi akan dilakukan untuk materi-materi (a) Pengertian dan Definisi Green Economy dan Kebijakan pemerintah yang berkaitan, (b) Maksud dan Tujuan Green Economy, (c) Mengenal kerusakankerusakan lingkungan akibat tidak diterapkannya green economy. (d) Penerapan Green Economy di lingkungan siswa dan masyarakat, (e) Teknik sederhana penerapan 3 pilar green economy (Reuse, Reduce dan Recycle), (f) Mengenalkan dan memberdayakan peluangusaha dalam era green economy, (g) Pengenalan pembuatan produk ramah lingkungan berupa edible water bottle sebagai produk ramah lingkungan dan produk alternatif pengganti gelas plastik.

Teknik evaluasi kegiatan dilakukan untuk menilai keberhasilan kegiatan ini adalah dalam bentuk memberikan pre test dan post test berkaitan dengan materi yang dibicarakan dalam kegiatan ini untuk mengetahui efektivitas kegiatan pengabdian masyarakat yang dilakukan untuk memberikan tambahan pengetahuan dan memotivasi seluruh peserta agar menjadi wirausaha muda yang berwawasan lingkungan.

Kata kunci: Green Economy, Wirausaha, Wawasan Lingkungan.

\section{PENDAHULUAN}

Isu lingkungan hidup hingga saat ini menjadi perhatian penting bagi seluruh dunia seiring dengan banyaknya masalah yang mengancam lingkungan hidup manusia seperti global warming, penipisan lapisan ozon, pencemaran udara, air dan tanah. Penerapan green economy sebagai bentuk kesadaran masyarakat dunia akan pentingnya lingkungan terhadap masa depan telah gencar dilakukan. Peningkatan kualitas disetiap bidang kenegaraan tanpa mengabaikan lingkungan telah dilaksanakan diberbagai negara (UNEP, 2011). Pergerakan ekonomi hijau kepada masyarakat memang membutuhkan waktu dan usaha, sehingga diperlukan kerjasama yang baik antara pemerintah, perusahaan, institusi pendidikan, masyarakat dan konsumen (Nagaruju, 2016).

Merespon kondisi ini UNESCO mencanangkan periode tahun 2002 - 2014 adalah periode untuk melaksanakan pendidikan untuk pembangunan yang berkelanjutan (education for sustainable development) pada World Summit di Johannesburg, September 2002 (Venkataraman, 2009) . Adapun tujuannya adalah "to empower people with the perspectives, knowledge, and skills for helping them live in peaceful sustainable societies" yang berarti untuk memberdayakan masyarakat dengan perspektif, pengetahuan, dan keterampilan untuk membantu mereka hidup dalam masyarakat yang damai berkelanjutan (Bird et al., 2008). 
Berkaitan dengan hal tersebut diatas maka pendidikan dapat menjadi salah satu cara merubah sikap dan perilaku masyarakat. Pengaruh yang ditimbulkan pendidikan memberikan dampak pada bertambahnya pengetahuan dan keterampilan serta akan menolong dalam pembentukan sikap yang positif.

Pendidikan kejuruan di SMK dikembangkan untuk menyiapkan dan/atau meningkatkan kualifikasi sumber daya manusia sebagai tenaga kerja terlatih memasuki dunia kerja yang menguntungkan bagi dirinya. Orientasi pengembangan pendidikan kejuruan akan diarahkan kepada program-program keahlian yang dapat memberikan pengetahuan, keterampilan, sikap kerja, pengalaman, wawasan, cara-cara berfikir kritis, kemampuan berkomunikasi efektif baik secara oral dan tertulis, berjiwa entrepreneurship, mampu mengakses dan menganalisis informasi, memiliki rasa ingin tahu dan mampu berimajinasi, serta memiliki jaringan yang dapat membantu diri siswa mendapatkan pekerjaan yang sesuai dengan pilihannya.

Proses produksi dalam berbagai sektor usaha dan industri di Indonesia sebagian besar dikerjakan oleh tenaga kerja yang dihasilkan oleh Sekolah Menengah Kejuruan (SMK). Untuk itu, sistem pendidikan SMK harus dapat mewujudkan kebutuhan tenaga kerja tingkat menengah yang mempunyai sikap serta perilaku adaptif, berjiwa kreatif dan professional sesuai bidangnya. Oleh sebab itu baik pendidikan lingkungan hidup maupun pendidikan ekonomi di sekolah harus pula menyertai kemampuan spesialisasinya. Siswa terbiasa bersikap kritis dan tanggap terhadap isu-isu lingkungan yang terjadi di sekelilingnya, baik dalam sikap dan perilaku mereka dalam kehidupan sehari-hari, di sekolah maupun di lingkungan tempat tinggalnya. Sehingga keberadaan pendidikan ekonomi dan pendidikan lingkungan hidup di SMK menjadi penting untuk membentuk perilaku konsumsi yang berkelanjutan (Muaddab, 2015). Begitu pula dengan tingkat kepercayaan terhadap produk-produk ramah lingkungan, umumnya lebih banyak ditemukan pada demografis jenis pekerjaan siswa atau pelajar (Zulfikar dan Mayvita, 2017).

Sekolah Menengah Kejuruan (SMK) merupakan salah satu sasaran tepat yang berperan besar dalam melahirkan para wirausaha muda di suatu daerah. SMK merupakan salah satu bentuk satuan pendidikan formal yang menyelenggarakan pendidikan kejuruan pada jenjang pendidikan menengah sebagai lanjutan dari SMP, MTs, atau bentuk lain yang sederajat atau lanjutan dari hasil belajar yang diakui sama atau setara SMP atau MTs (PP No. 66 Tahun 2010).

Berdasarkan informasi yang diperoleh melalui hasil wawancara dengan pihak sekolah yaitu Bapak Drs. H. Muryadi, SH. MM (Kepala Sekolah) yang menjadi mitra pengusul yaitu SMKN 3 Banjarmasin, pendidikan tentang lingkungan hidup ataupun ekonomi yang berbasis lingkungan belum terlalu banyak ditekankan kepada para siswa didik sehingga kegiatan-kegiatan berupa sosialisasi konsep green economy sangat diharapkan oleh sekolah ini untuk memberikan pembekalan pengetahuan kepada mereka jika mereka menjadi seorang wirausaha di masa yang datang.

Berdasarkan hal di atas, maka kegiata oengabdian masyaraat ini dilakukan guna mempersiapkan siswa MKN 3 Banjarmasin menjadi wirausaha muda yang berwawasan linngkungan.

\section{METODE KEGIATAN}

Tujuan Kegiatan pengabdian masyarakat ini adalah untuk memberikan pemahaman dan tambahan pengetahuan kepada siswa SMKN 3 Banjarmasin tentang konsep green economy, meningkatkan motivasi para siswa untuk menjadi wirausaha muda yang berwawasan lingkungan, 
mandiri dantangguh dan memperkenalkan teknik-teknik penerapan green economy secara sederhana yang dapat diterapkan di lingkungan para siswa baik di sekolah maupun di tempat tinggal masing-masing.

Sedangkan manfaat yang diharapkan dari kegiatan ini adalah siswanantinya memiliki pola pikir dan pengetahuan baru bahwa kegiatan ekonomi yang nantinya akan dilaksanakan setelah mereka lulus haruslah berwawasan lingkungan, siswa memiliki pengetahuan dan dalam menerapkan 3 pilar green economy yaitu Reduce, Reuse dan Recycle dalam kehidupan mereka sehari-hari dan siswa mendapatkan gambaran peluang usaha yang bisa digarap dengan menerapkan green economy.

Metode pelaksanaan kegiatan ini dilakukan dalam 2 tahapan yaitu (1) tahap persiapan dan (2) tahap kegiatan. Tahap persiapan dilakukandengan mengadakan survey pendahuluan ke lokasi mitra. Survei dilakukan untuk mengetahui kesediaan mitra untuk bekerjasama dengan tim pengusul dan untuk mengetahui permasalahan mitra, menetapkan solusi bersama yang akan dilaksanakan, waktu pelaksanaan, menentukan kriteria siswa yang akan dijadikan peserta kegiatan dan mendiskusikan strategi yang akan dilakukan dalam kegiatan yaitu bagaimana teknik memancing atau merangsang perhatian (attention) siswa, relevansi (relevance) antaramateri pelatihan dengan keterampilan siswa dan kepuasan (satisfaction) siswa dan sekolah setelah diadakannya workshop. Strategi ini digunakan dalam kegiatan agar berjalan lebih menarik, bersemangat dan membangkitkan motivasi para siswa dalam mempelajari dan menggali tentang konsep green economy.

Khalayak sasaran dari kegiatan ini adalah para siswa SMKN 3 kelas XII Banjarmasin yang berasal dari 6 kompetensi keahlian yaitu : usaha perjalanan wisata, akomodasi perhotelan, akuntansi, administrasi Perkantoran, Pemasaran dan Multimedia.

Evaluasi kegiatan dilakukan dalam bentuk memberikan kuesioner kepada peserta yang bertujuan untuk :

- Mengetahui kinerja kegiatan berdasarkan 3 indikator penilaian yaitu kualitas pemateri, relevansi materi dan ketersediaaan sarana/fasilitas kegiatan

- Mengetahui tingkat pemahaman dan motivasi peserta dalam bentuk pre dan post test berdasarkan 3 materi utama kegiatan yaitu materi (1) Konsep dasar green economy, (2) Pilar dan Penerapan Green Economy serta (3) Produk green economy.

\section{PELAKSANAAN DAN PEMBAHASAN}

\section{Persiapan Kegiatan}

Persiapan kegiatan dilakukan dalam 2 (dua) kali pertemuan yakni :

a. Pertemuan pertama, merupakan kunjungan awal tim pelaksana dan bertemu dengan pihak sekolah SMKN 3 Banjarmasin pada tanggal 26 September 2017 untuk menyampaikan maksud dan tujuan kegiatan, penentuan syarat peserta serta pengusulan tanggal pelaksanaan kegiatan.

b. Pertemuan kedua pada tanggal 31 September 2017 untuk menyepakati penetapan tanggal pelaksanaan kegiatan yaitu pada hari Rabu tanggal 11 Oktober 2017 yang dihadiri oleh siswa kelas XII dan merupakan perwakilan dari 6 kompetensi yang ada di SMKN 3 Banjarmasin. 


\section{Pelaksanaan Kegiatan}

Kegiatan pengabdian kepada masyarakat ini dilaksanakan pada hari Rabu tanggal 11 Oktober 2017 yang dimulai pada pukul 08.00 sampai dengan pukul 12.00 WITA, bertempat di aula kegiatan SMKN 3 Banjarmasin yang beralamat di Jalan Pramuka Komplek Semanda No 52 kelurahan Sungai Lulut Kecamatan Banjarmasin Timur yang diikuti oleh 57 orang siswa Kelas XII SMKN 3 Banjarmasin. Dokumentasi kegiatan dapat dilihat pada gambar 1 di bawah ini.
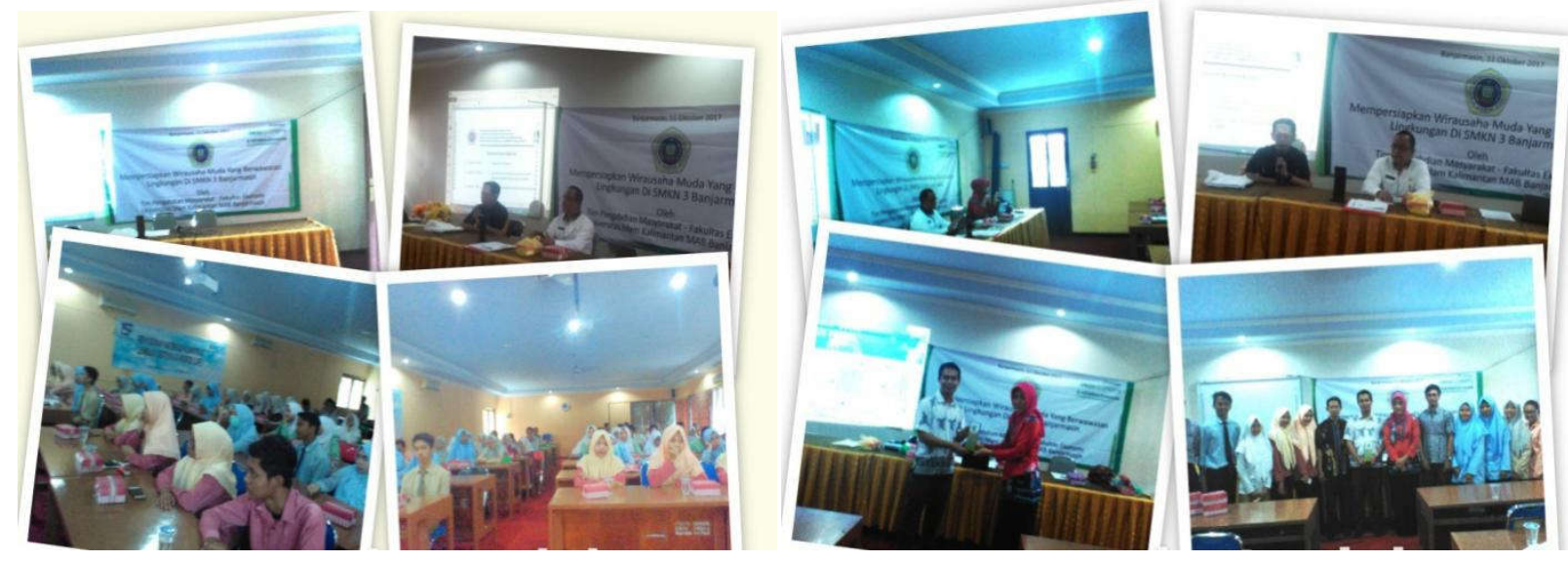

\section{Gambar 1. Dokumentasi Kegiatan Pengabdian Masyarakat Green Economy Workshop}

Pelaksanaan kegiatan dilakukan dengan beberapa metode yakni metode ceramah dan diskusi serta pengenalan teknik green economy dan produk ramah lingkungan dengan menggunakan media audio visual (video).

\section{1) Ceramah dan Diskusi}

Dalam ceramah dan diskusi disampaikan beberapa materi yang tidak hanya berkaitan green economy, tetapi juga disampaikan materi tentang profil Universitas Islam Kalimantan MAB Banjarmasin dan sekilas tenttang materi kewirausahaan. Dalam kegiatan ini para peserta cukup antusias memperhatikan materi yang disampaikan dan hal ini terlihat pada session tanya jawab dimana para peserta cukup banyak mengajukan pertanyaan dan tanggapan yang mengindikasikan ketertarikan peserta dengan materi yang disampaikan.

Adapun materi-materi yang disampaikan dalam session ceramah dan diskusi antara lain adalah :

a) Materi pengenalan Universitas Islam Kalimantan MAB Banjarmasin yang berisi tentang Misi, Visi, Prestasi, Sarana dan Prasarana serta kegiatan ekstrakurikuler mahasiswa Uniska.

b) Materi Green Economy yang berisi tentang dampak kerusakan lingkungan, Black economy Vs Green Economy, keselarasan Green Economy dan Sustainable Development, Pilar green economy, Produk-produk green economy, strategi Go green in School, potensi dan peluang usaha di era green economy. 


\section{2) Presentasi dengan media audio visual.}

Pada tahap ini, penyampaian materi dilakukan dengan bantuan audio visual atau video interactive yang berisikan materi-materi sebagai berikut :

\section{a) Teknik Reduce, Recycle dan Reuse dengan media Visual}

Dalam kegiatan ini para peserta diberikan pengetahuan dengan media visual atau video tentang teknik-teknik sederhana menerapkan Reduce, Recycle dan Reuse dalam kehidupan sehari-hari seperti mengurangi pemakaian kertas dan plastik, mendaur ulang dan penggunaan limbah plastik seperti botol dan gelas plastik. Video yang berdurasi selama 5 menit dan didapat dari website www.youtube.com ini cukup menarik perhatian para peserta karena adanya beberapa teknik sederhana penerapan Reduce, Recycle dan Reuse yang cukup mudah untuk diterapkan baik di lingkungan sekolah maupun di lingkungan pribadi masing-masing peserta.

Ada beberapa tindakan yang harus dilakukan masyarakat sebagai salah satu wujud perilaku yang ramah lingkungan yang sering dikenal dengan 3R (Reduce, Reuse dan Recycle) yaitu:

- Reduce

Reduce atau mengurangi dapat diartikan menggunakan lebih sedikit (Mills, 2012). Konsumen yang menggunakan lebih sedikit produk yang mencemari lingkungan dan beralih atau lebih mengkonsumsi produk yang ramah lingkungan merupakan langkah yang sederhana namun dapat meminimalkan dampak lingkungan.

\section{- Reuse}

Reuse atau menggunakan kembali dapat diartikan menggunakan produk lagi sesuai dengan kegunaannya (Mills, 2012). Konsumen yang mengurangi kebutuhan akan produk baru dapat membantu mengurangi sampah atau limbah yang dapat mencemari lingkungan.

- Recycle

Recycle atau daur ulang merupakan proses mengolah sampah menjadi bahan atau produk baru (Mills, 2012). Hasil daur ulang yang berupa bahan atau produk tersebut dapat menjadi sumber daya yang berharga dan berguna bagi industri manufaktur.

\section{b) Pengenalan Produk Ramah Lingkungan}

Dalam kegiatan ini, para peserta dikenalkan dengan produk ramah lingkungan yaitu edible water bottle yang merupakan produk alternatif pengganti gelas plastik dan disampaikan dengan metode audio visual. Edible Water Bottle (EWB) adalah produk tempat minum yang dapat dimakan berbentuk bola yang terbuat dari sodium alginat yang berasal dari rumput laut dan kalsium laktat yang sering digunakan dalam produk pangan. Dengan cara pengolahan yang sederhana produk EWB ini dapat menggantikan fungsi gelas plastik yang saat ini masih banyak digunakan (Clementes, 2015).

Dalam session ini dijelaskan tentang produk dan manfaat edible water bottle baik untuk lingkungan maupun untuk kesehatan dan juga ditampilkan video tentang produk EWB. 


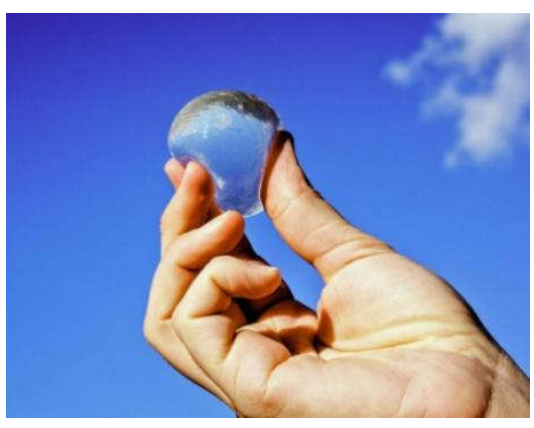

\section{Gambar 2. Produk Edible Water Bottle}

Bahan utama pembuatan EWB adalah sodium alginat dan kalsium laktat. Sodium alginat diekstrak dari rumput laut coklat dan banyak digunakan sebagai stabiliser dna emulsifier untuk produk-produk pangan seperti ice cream, yogurt, krim salad, keju, agar-agar dan makanan kaleng. Sodium alginat (E401) biasanya digunakan bersamaan dengan kalsium laktat. dan bila dicampur dengan kalsium akan membentuk lapisan luar yang kenyal namun tetap cair di bagian dalamnya (Ferdinand, 2010).

Fungsi alginat dalam industri pangan dianggap cukup penting, sebagai salah satu alternatif bahan tambahan makanan yang halal. Fungsi alginat pada prinsipnya dapat menggantikan gelatin atau lemak hewan yang berfungsi sebagai stabilizer-emulsifier dan pengental penstabil emulsi (Winarno, $2008: 85$ ).

Menurut Sudrajat (2011), konsumsi sodium alginat secara teratur dapat menghambat penyerapan kolesterol dan glukosa pada usus halus sehingga sangat berguna untuk pencegahan kegemukan (obesitas), menurunkan kolesterol dan menurunkan kadar gula darah pada penderita diabetes. Selain kegunaan tersebut telah dilaporkan pula bahwa bentuknya yang berupa gel di dalam lambung, sodium alginat juga dapat mengurangi peradangan lambung (maag), dan melancarkan pencernaan. Telah diketahui juga bahwa bahwa bahan makanan yang berasal dari rumput laut mengandung kadar serat yang tinggi sehingga dapat menunda rasa lapar, oleh karena itu sodium alginat ini juga dapat digunakan untuk diet, mempertahankan struktur normal sel, menyampaikan pesan syaraf ke otak dan untuk kontraksi otot jantung.

Melihat kandungan dari EWB maka dapat dipastikan bahwa produk EWB bermanfaat sekali untuk kesehatan dan dapat menjadi salah satu alternatif produk kesehatan dengan biaya murah.

Adapun cara pembuatan produk Edible Water Bottle adalah sebagai berikut :

1. Siapkan 1 liter air minum dalam wadah dan campurkan 5 mg Sodium laktat.

Lakukan pengadukan selama 3 menit hingga semua bahan tercampur merata.

Larutan ini bisa disebut dengan larutanA.

2. Di wadah lain yang terpisah, siapkan 1 liter air dan campurkan $5 \mathrm{mg}$ Calsium Laktat. Lakukan pengadukan selama 3 menit hingga semua bahan tercampur merata. Larutan ini bisa disebut dengan larutan B.

3. Larutan A diambil dengan mengunakan sendok makan dan letakkan secaraa perlahan di dalam larutan B. Biarkan beberapa saat proses pembentukan EWB terjadi.Angkat produk EWB secara perlahan dan bisa dimasukkan ke pendingin untuk menghasilkan EWB dengan kemasan yang lebih tebal. 
Video yang berdurasi selama 5 menit dan didapat dari website www.youtube.com dianggap merupakan informasi baru bagi para peserta dan dinilai ini cukup menarik karena proses pembuatan yang sederhana dan bahan baku pembuatan EWB tersedia dengan harga yang cukup murah.

\section{Evaluasi Kegiatan}

Dalam rangka menilai hasil kegiatan, maka evaluasi yang dilakukan antara lain adalah :

a) Menilai kinerja kegiatan dalam bentuk kuesioner penilaian umum kegiatan yang berkaitan tentang. kualitas pemateri, bahan materi presentasi, sarana dan fasilitas kegiatan.

b) Mengetahui tingkat pemahaman dan motivasi peserta dalam bentuk kuesioner pre dan post test.

Untuk mengidentifikasi kecenderungan tiap-tiap skor penilaian evaluasi selanjutnya digunakan nilai rerata $(\mathrm{M})$ dan standar deviasi (SD) dari semua objek dalam tiap indikator penilaian. Dari nilai rerata dan standar deviasi tersebut, kemudian diidentifikasi dikelompokkan dalam kategori sebagai berikut (Hadi, 2002: 135) :
a) Tinggi
$=\mathrm{X} \geq \mathrm{M}+\mathrm{SD}$
b) Sedang
$=\mathrm{M}+\mathrm{SD}>\mathrm{X} \geq \mathrm{M}-\mathrm{SD}$
c) Rendah
$=\mathrm{M}-\mathrm{SD}>\mathrm{X}$

Adapun hasil evaluasi kegiatan yang diperoleh adalah sebagai berikut :

\section{- Penilaian Umum Kinerja Kegiatan}

Hasil penilaian peserta tentang kinerja kegiatan yang telah dikategorisasi dengan skala tingg, sedang dan rendah berdasarkan 3 indikator penilaian seperti kualitas pemateri, relevansi materi dan ketesediaan sarana/fasilitas kegiatan, dapat dilihat pada tabel 1 dan gambar 3 berikut ini.

\section{Tabel 1.}

Hasil ketegorisasi Penilaian Kinerja kegiatan

\begin{tabular}{|c|l|c|c|c|c|}
\hline \multirow{2}{*}{ No } & \multicolumn{1}{|c|}{ Materi } & \multicolumn{3}{|c|}{ Hasil Kategorisasi } & \multirow{2}{*}{ Jumlah } \\
\cline { 3 - 5 } & & Bagus & Cukup & $\begin{array}{c}\text { Tidak } \\
\text { Bagus }\end{array}$ & \\
\hline 1 & & & 27 & 0 & 57 \\
2 & Kualitas Pemateri & 30 & 23 & 0 & 57 \\
3 & Relevansi Materi & 34 & 25 & 0 & 57 \\
\hline
\end{tabular}

Sumber : Data Kegiatan, 2018 (diolah)

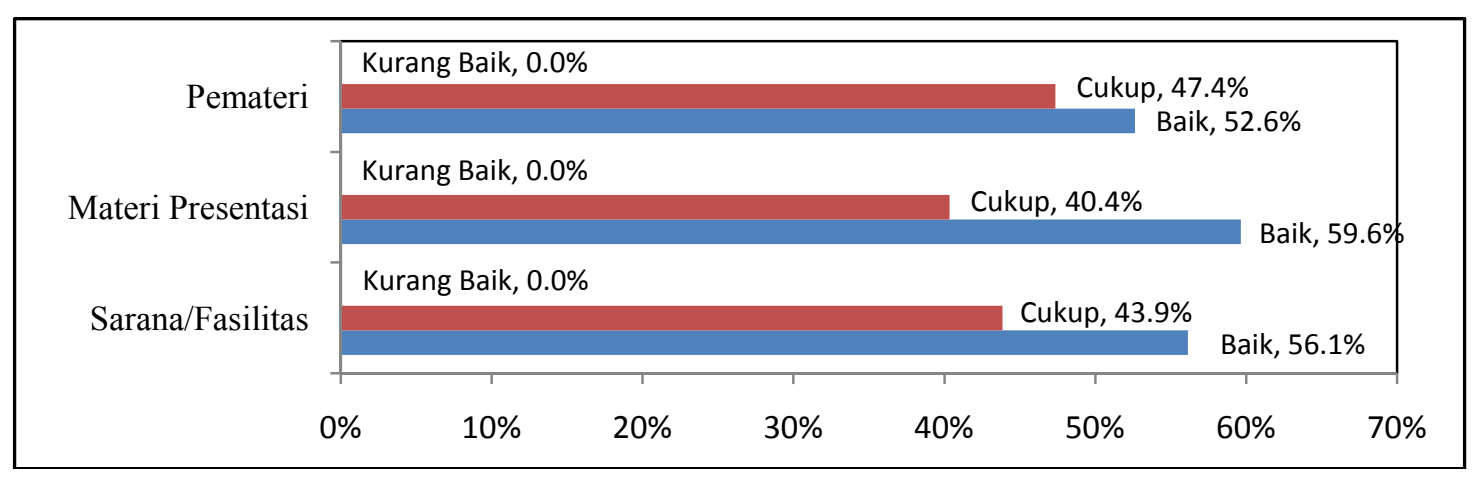

Gambar 3. Hasil Evaluasi Kinerja Kegiatan 


\section{- $\quad$ Tingkat Pemahaman dan Motivasi Peserta}

Hasil pre dan post test dikategorisasi berdasarkan 3 skala penilaian yaitu tinggi, sedang dan rendah. Materi evauasi berupa penilaian terhadap tingkat pemahaman dan motivasi peserta atas materi konsep dasar, pilar dan penerapan dan produk-produk green economy. Hasil kategorisasi evaluasi tingkat pemahaman dan motivasi peserta dapat dilihat pada tabel 2 dan gambar 4, 5 dan 6 berikut ini.

Tabel 2.

Kategorisasi Hasil Pre - Post Test Tingkat Pemahamann dan Motivasi Peserta

\begin{tabular}{|c|l|c|c|c|c|c|c|c|}
\hline \multirow{2}{*}{ No } & \multirow{2}{*}{ Materi } & \multicolumn{3}{|c|}{ Pre Test (Orang) } & \multicolumn{3}{c|}{ Post Test (Orang) } & Jumlah \\
\cline { 3 - 9 } & & Rendah & Sedang & Tinggi & Rendah & Sedang & Tinggi & \\
\hline 1 & Konsep dasar & 28 & 19 & 10 & 5 & 3 & 49 & 57 \\
\hline 2 & Pilar \& Penerapan & 32 & 18 & 7 & 0 & 2 & 55 & 57 \\
\hline 3 & Produk & 22 & 20 & 15 & 1 & 15 & 41 & 57 \\
\hline
\end{tabular}

Sumber : Data Kegiatan, 2018 (diolah)

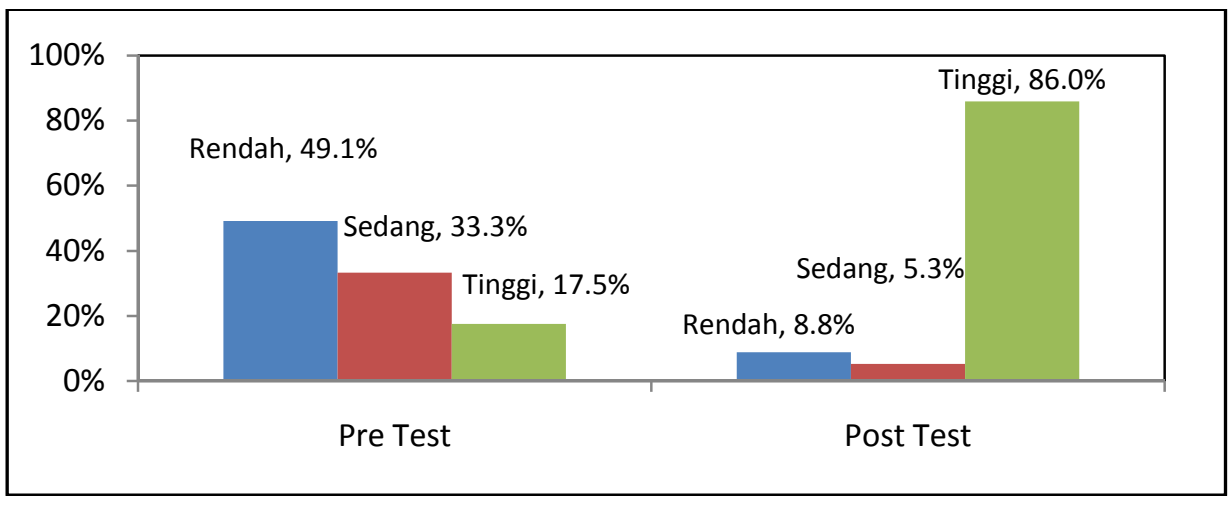

Gambar 4. Perbandingan Skor Pre - Post Test Materi Konsep Dasar

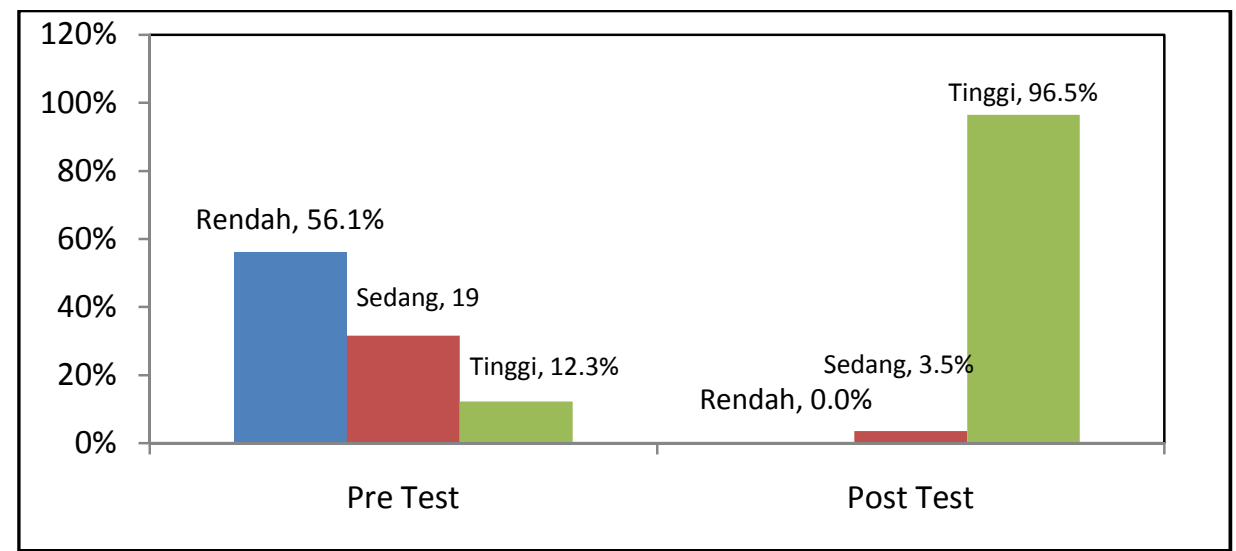

\section{Gambar 5. Perbandingan Skor Pre - Post Test Materi Pilar dan Penerapan Green Economy}




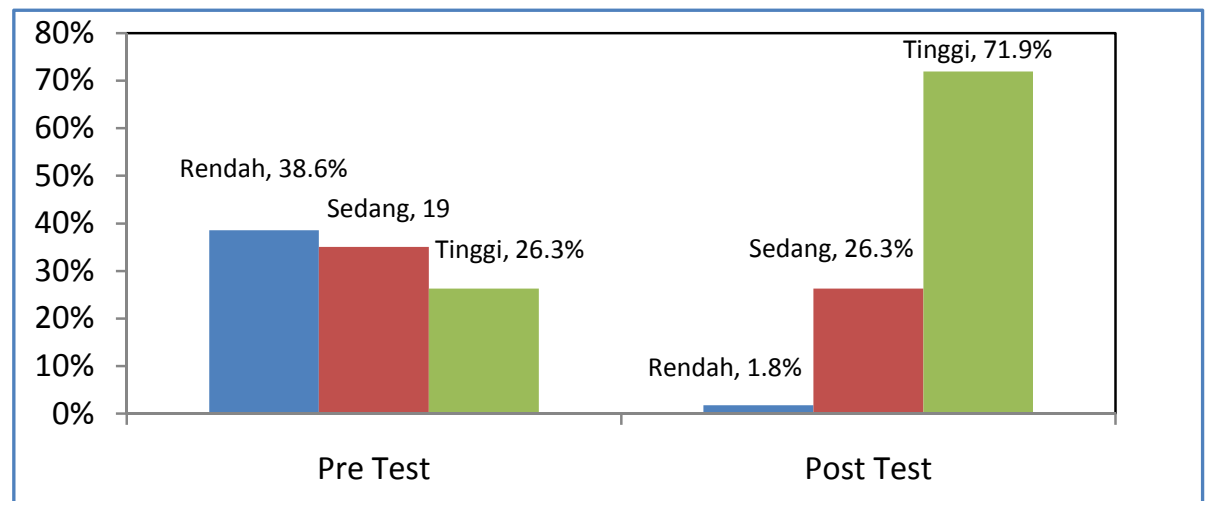

Gambar 6. Perbandingan Skor Pre - Post Test Materi Produk Green Economy.

Berdasarkan hasil skor pre dan post test di atas maka sangat jelas terlihat bahwa terjadi peningkatan rata-rata skor test peserta secara signifikan dimana skor test kategori tinggi semakin meningkat setelah mengikuti kegiatan dan dapat dikatakan bahwa dengan adanya kegiatan ini telah memberikan manfaat berupa tambahan pengetahuan, pemahaman dan motivasi kepada peserta mengenai konsep green economy, penerapan dan jenis produknya.

\section{Kendala dan Solusi}

Dalam melaksanakan kegiatan ini kendala yang dihadapi adalah terbatasnya jumlah siswa yang dapat mengikuti kegiatan workshop ini karena pelaksanaan kegiatan dilakukan pada hari sekolah, sehingga dirasakan efek kegiatan ini sangat terbatas dan belum optimal dengan minimnya jumlah peserta.

Solusi yang dilakukan adalah pada saat pelaksanaan kegiatan, pemateri menyampaikan dan mengharapkan agar informasi yang didapat peserta yang hadir dapat ditransfer ke rekan-rekan siswa lainnya sehingga pengetahuan yang didapat dalam kegiatan ini bisa dibagikan kepada para siswa yang tidak menghadiri kegiatan tersebut.

\section{KESIMPULAN DAN SARAN}

\section{Kesimpulan}

Beberapa hal yang dapat disimpulkan atas pelaksanaan kegiatan pengabdian masyarakat di SMKN 3 Banjarmasin adalah sebagai berikut:

a) Kegiatan diiikuti oleh 57 siswa kelas XII yang merupakan wakil dari 6 bidang kompetensi yang ada di SMKN 3 Banjarmasin yaitu usaha perjalanan wisata, akomodasi perhotelan, akuntansi, administrasi Perkantoran, Pemasaran dan Multimedia.

b) Para peserta kegiatan sangat tertarik tentang konsep green economy dan antusias dalam mengikuti kegiatan yang dilihat dari banyaknya pertanyaan yang disampaikan oleh peserta.

c) Masih adanya kendala keterbatasan jumlah peserta dalam pelaksanaan kegiatan, sehingga efek kegiatan ini dirasakan masih terbatas dan belum optimal dengan minimnya jumlah peserta.

d) Pelaksanaan kegiatan dinilai positif oleh peserta yang dilihat dari hasil penilaian kinerja kegiatan yang mayoritas masuk dalam kategori baik. 
e) Kegiatan yang dilaksanakan terbukti efektif memberikan tambahan pengetahuan dan pemahaman tentang green economy yang terlihat dari hasil skor post test yang rata-rata memberikan hasil yang lebih baik daripada skor pre test.

\section{Saran}

Berdasarkan hasil kegiatan, maka dapat disarankan beberapa hal sebagai berikut :

a) Perlu adanya komitmen pihak sekolah untuk menyediakan waktu yang cukup bagi pelaksana kegiatan sesuai dengan target materi yang akan disampaikan untuk pelaksanaan kegiatan pengabdian masyarakat di masa yang akan datang.

b) Sekolah kejuruan dapat dijadikan sebagai tempat untuk mempersiapkan young green enterpreneur dan hal yang dapat dilakukan adalah memberikan pengetahuan yang cukup kepada siswa tentang kewirausahaaan yang berorientasi lingkungan dengan menyisipkan materi-materi tentang green economy di dalam materi-materi wajib di sekolah.

c) Perlu adanya kerjasama yang baik dari seluruh pihak sekolah untuk dapat melaksanakan kegiatan go green di sekolah agar SMKN 3 Banjarmasin dapat menjadi sekolah kejuruan yang berorientasi lingkungan (Green School).

\section{DAFTAR PUSTAKA}

Bird, E. Lutz, R dan Warwick, C. 2008 Media as Partners in Education for Sustainable Development: A Training and Resource Kit. United Nations Scientific, Educational and Cultural Organization (UNESCO) Series on Journalism Education (Paris: UNESCO, 2008): 42.

Clements, D. 2015. Meet Ooho The Edible Plastic Free Water Bottle. http://www.discovery.com/dscovrd/tech/meet-ooho-the-edible-plastic-free-water-bottle/. Diakses tanggal 1 Juli 2017

Ferdinand, S. 2010. Kalsium / Calsium dan manfaat serta fungsi dalam tubuh. https://b57ev.wordpress.com/2010/06/22/kalsium-calsium-dan-manfaat-serta-fungsi-dalamtubuh/. Diakses pada tanggal 1 Juli 2017.

Hadi, S. (2002). Metodologi Riset. Andi Ofset. Yogyakarta.

Mills, R. M.. 2012. What It Means to Go Green: Reduce, Reuse, Repurpose, and Recycle. Logan. Utah State University.

Muaddab, H. 2015. Faktor Yang Berpengaruh Terhadap Perilaku Konsumsi Hijau Pada Siswa SMK Negeri Se Kabupaten Jombang. Edusentris : Jurnal Ilmu Pendidikan dan Pengajaran.. $2(2): 126-145$.

Nagaraju, B. dan Thejaswini H.D. 2016.A Study On Consumer Attitude Towards Eco-Friendly FMCG Products With Reference To Hubli City In Karnataka. IOSR Journal Of Business And Management (IOSR-JBM). Vol.18 (11): 58-63.

Peraturan Pemerintah No. 66. 2010. Perubahan Atas Peraturan Pemerintah Nomor 17 Tahun 2010 Tentang Pengelolaan Dan Penyelenggaraan Pendidikan. Dikeluarkan Oleh Kantor Kementerian Hukum Dan Hak Asasi Manusia Republik Indonesia Tanggal 28 September 2010. Jakarta. 
Sudrajat, Y. 2011. Manfaat Kapsul Sodium Alginat Untuk Kesehatan. http://kapsulsodiumalginat-yayat.blogspot.co.id/2011/06/manfaat-kapsul-sodium-alginatbagi.html. Diakses tanggal 1 Juli 2017.

Venkataraman, B. 2009. Educational For Sustainable Development. Environment Magazine. Maret-April 2009. $51(2): 8-10$.

Winarno, F.G. 2008. Teknologi Pengelolaan Alga Laut. Edisi 2. Pustaka Sinar harapan. Jakarta.

Zulfikar, R., \& Mayvita, P. A. (2017, December). Tingkat Kepercayaan dan Minat Beli Masyarakat Banjarmasin Terhadap Produk Hijau Berdasarkan Segmentasi Demografis. In Proceeding of National Conference on Asbis (Vol. 2, No. 1, pp. 410-426).

Zulfikar, R., \& Mayvita, P. A. (2018). The Relationship of Perceived Value, Perceived Risk, and Level of Trust Towards Green Products of Fast Moving Consumer Goods Purchase Intention. JEMA: Jurnal Ilmiah Bidang Akuntansi dan Manajemen, 15(2), 1-14.

Zulfikar, R., \& Banjarmasin, U. I. K. M. The Structural Equation Models Of Environmental Concern and Knowledge To Green Trust and Green Purchase Intention Towards Green Products (Guideliness).

Zulfikar, R., \& Mayvita, P. A. (2019). Does Green Economy Video Really Work? The Effectiveness of Using Video Content Marketing in Forming MSMEs Perception and Behavior to Implement Green Economy. JEMA: Jurnal Ilmiah Bidang Akuntansi dan Manajemen, 16(1), 34-45.ar

Zulfikar, R., \& Mayvita, P. A. (2019). DIVERSIFIKASI PRODUK OLAHAN BERBASIS IKAN PATIN SEBAGAI POTENSI USAHA BAGI PANTI ASUHAN AL AMIN DAN SULTAN SURIANSYAH BANJARMASIN. JURNAL PENGABDIAN AL-IKHLAS UNIVERSITAS ISLAM KALIMANTAN MUHAMMAD ARSYAD AL BANJARY, 4(1). 